2018-01-02

The responsibilisation of teachers: a neoliberal solution to the problem of inclusion

\title{
Done, Elizabeth
}

http://hdl.handle.net/10026.1/12257

\subsection{0/01596306.2016.1243517 \\ Discourse: Studies in the Cultural Politics of Education Informa UK Limited}

All content in PEARL is protected by copyright law. Author manuscripts are made available in accordance with publisher policies. Please cite only the published version using the details provided on the item record or document. In the absence of an open licence (e.g. Creative Commons), permissions for further reuse of content should be sought from the publisher or author. 


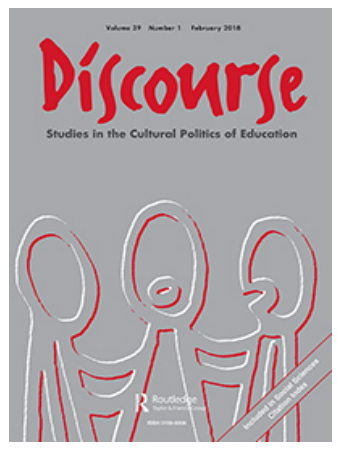

Discourse: Studies in the Cultural Politics of Education

\section{The responsibilisation of teachers: a neoliberal solution to the problem of inclusion}

\section{Elizabeth J. Done \& Mike Murphy}

To cite this article: Elizabeth J. Done \& Mike Murphy (2018) The responsibilisation of teachers: a neoliberal solution to the problem of inclusion, Discourse: Studies in the Cultural Politics of Education, 39:1, 142-155, DOI: 10.1080/01596306.2016.1243517

To link to this article: https://doi.org/10.1080/01596306.2016.1243517

\section{曲 Published online: 09 Oct 2016.}

Submit your article to this journal $\pi$

Џll Article views: 508

View Crossmark data ¿ 


\title{
The responsibilisation of teachers: a neoliberal solution to the problem of inclusion
}

\author{
Elizabeth J. Done and Mike Murphy \\ Institute of Education, Plymouth University, Plymouth, UK
}

\begin{abstract}
This paper critically examines competing demands placed on teachers, with reference to recent inclusion policy in England and Australia. The authors draw on Michael Foucault's analysis of power, neoliberalism(s) and biopolitics to explore the ways in which teachers are 'responsibilised' into negotiating and fulfilling demands related to both state-imposed accountability practices and social justice agendas. The economic context and associated 'politics of austerity' are taken into account in a critical exploration of how the (biopolitical) management of inclusion in the neoliberal present coincides with diminishing funding for social and educational expertise, with ever-increasing responsibilities being placed on teachers to fill this void. The responsibilisation of teachers in recent legislation and statutory guidance discursively constructs the teacher as a professional who takes responsibility for student and school performance, pastoral care, inclusion and social change. Responsibilisation relies on 'dividing practices', obliging some teachers to assess the conformity of colleagues to inclusion policy.
\end{abstract}

\section{KEYWORDS}

Foucault; educational neoliberalisation; inclusion; responsibilisation; dividing practices; biopolitics

\section{Introduction}

This paper takes policies and practices related to inclusion as its starting point in a critical evaluation of the role of teachers within neoliberal educational contexts. Over recent decades, the structural reforms needed to marketise the educational domain have been accompanied by neoliberal educational discourses which emphasise freedom, for example, parents' freedom to select their child's school as consumers of educational services. Such freedom, for teachers, has meant participation in school league tables, competition for funding, subjecting pupils to intensive testing regimes and the rating of school performance against externally imposed criteria (Moore \& Clarke, 2016). The neoliberal process of marketisation has required teachers to negotiate and implement numerous policy initiatives, including those linked to political discourses around social justice which acknowledge the varied obstacles to free and fair competition. This high level of political intervention can be difficult to reconcile with neoliberal economic theories which explicitly link marketisation with a diminished role for the state. A key argument 
presented in this paper is that Foucault's (2008) analyses of neoliberalism bear directly on this apparent contradiction.

Foucault's (2008) study of three schools of neoliberal thought (American, Austrian and German) is linked to a broader analysis of the development of the modern state (1982, 2007), and both are pertinent to the issues of teacher identity and workload. Below, Foucault's (1982) account of the development of the modern state and its relevance to the neoliberal educational present and formation of teachers' professional identities is outlined. Foucault's (2008) study of ordo-liberalism, as a distinctive school of neoliberal thought, is then introduced and key differences within ordo-liberal thought are identified. It is argued that educational inclusion is now a site where distinctive versions of ordo-liberalism uneasily co-exist and the implications for teachers are critically explored. Finally, we consider the ways in which 'dividing practices' and 'systems of differentiation' (Foucault, 1982, p. 777) not only affect hitherto marginalised groups but also teachers in a 'government of individualization' (p. 781).

\section{Background}

In The Subject and Power, Foucault (1982) is concerned with the power relations and technologies which characterise the modern state, the historical shifts that have facilitated their development and, ultimately, with the 'modes of objectification that transform human beings into subjects' (p. 777). Two meanings of 'subject' are outlined: 'subject to someone else by control and dependence; and tied to his own identity by a conscience or self-knowledge' (p. 781). Resistance involves questioning the 'techniques' of power through which such self-knowledge is produced (the 'subjection' of subjectivity) (p. 782). A defining feature of the modern state has been its integration, rather than displacement, of the pastoral power evidenced in earlier Christian institutions (p. 782). Historically, pastoral power featured: the deferment of salvation; a concept of self-sacrifice for the greater good; a dual focus on individual and community; and "knowledge of the conscience and an ability to direct it' (p. 783). Foucault charts historical changes in the meaning of salvation such that it was no longer to be deferred but referred, instead, to the health and welfare of populations, signalling the birth of the modern state and biopolitical power (p. 784).

Foucault (1982) argues that this historical shift depended on novel forms of knowledge which permeated the 'social body', one 'globalizing and quantitative, concerning populations' and another 'analytical, concerning the individual' (p. 784). Education is cited as one of several individualising knowledge practices that are integral to the biopolitical power of the modern state, that is, to the power technologies through which the state seeks to regulate the populations within its jurisdiction (Foucault, 1982, p. 787) and maintain the 'health of the social body' (Biebricher, 2011, p. 171).

\section{Performativity and inclusion}

The interplay between these individualising and totalising dimensions of biopolitical power is evidenced in educational performance league tables which require academic achievement to be individualised in order that the relative performance of schools can be scrutinised, managed and controlled. In the case of international comparisons, the 
educational 'health' of nation states can allegedly be gauged through statistical analyses that, by definition, are blind to the specificities of local context. Exley and Ball (2011) argue that this individualising and decontextualising of the performance of students and schools serves to depoliticise differences in academic attainment. Teachers are inextricably implicated in such performance rating practices, raising questions from a Foucauldian perspective about the forms of subjection at play. In Foucault's terms, neoliberal discourses of social accountability constitute a 'mode of objectification' of educational subjects (teachers and students) (1982, p. 783); teachers are reduced to the measurable impacts of their classroom practice within data sets of variable scope (local, regional, national and global). Moore and Clarke (2016) suggest that a sizeable proportion of teachers participate in such accountability procedures against their better judgment, and it is the individual teacher's 'production of truth' (Foucault, 1982, p. 783) about themselves or their professional identity that concerns us here.

Despite calls for the modification or abandonment of an increasingly global testing culture (e.g. Smith, 2016), Graham (2015, p. 16) argues that it is students who have traditionally been excluded from high stakes testing who are the 'victims of accountability frameworks' by virtue of that exclusion. On this account, teachers are required to 'accept the responsibility for creating schools in which all children can learn and feel they belong' (Rouse, 2008, p. 1), and attend to their school's position in performance league tables, and successfully incorporate hitherto excluded students into standardised performance and accountability procedures. Furthermore, political discourses around austerity which gained ground following the global financial crisis have generated additional demands on teachers. Statutory guidance in England, issued by the Department of Health and Department for Education (DoH/DfE, 2015) and based on legislation claiming to deliver inclusive education (DfE, 2013), insists that all teachers practise inclusively and cost-efficiently (DoH/DfE, 2015). This revised remit can be situated within broader 'attempts to reengineer professional identities' (Herr, 2015, p. 3) as objectives and practices from the private sector are imported into the public realm (Gunter, 2012). Teachers' production of truth about themselves and their practice, consequently, requires the negotiation of varied trends, including the construction of inclusion as participation in performativity; the importation of business management discourse into educational contexts; and a blurring of boundaries between previously distinct social, economic and educational networks (Foucault, 2008; Thrift, 2006).

\section{Teacher identities}

In Moore and Clarke (2016), the discourse of professionalism increasingly directed towards teachers works to facilitate their enactment of policies that conflict with their pedagogic beliefs and values. This discourse implies a 'cruel optimism' since enacting such polices can undermine those very same values (p. 666). We suggest below that a discourse of change agency, which is increasingly invoked in the educational inclusion literature, operates in a similar way; teachers who are sceptical that inclusion policy initiatives will deliver social justice, or who question the political motivation behind such initiatives, are encouraged to identify with the potentially seductive image of the teacher as change agent, that is, as a professional who can eventually bring about social change and create their desired educational environment, even if this means shorter term compliance with problematic 
policy directives. We have previously described such images, following Massumi (1998), as idealised abstractions that work to alter the educational environment (Murphy \& Done, 2014); but, in Foucault (1982), the circulation of such seductive images is explicitly framed as one of several biopolitical 'strategies' through which the state seeks to avert resistance and sustain a power relation. This strategy of fostering short-term compliance for an alleged longer term gain resonates with Foucault's (1982) description of the role of the concept of salvation in historical pastoral power. Overt resistance is deferred given the trade-off allegedly at stake; hence, teachers (as individuals) are led to believe that dutiful enactment of state policy will advance the interests of school sub-populations (communities) to which teachers are committed.

\section{Freedom and subjectivity}

Foucault (1982, p. 782) states that an understanding of power relations is best achieved by first looking at forms of resistance and then at the 'strategies' which act to limit that resistance. The aforementioned discourses of professionalism and change agency serve to illustrate, however, why teachers may choose to defer overt forms of resistance. The crucial point here is that freedom, whether it is the freedom to comply or resist in the case of teachers or parental freedom to make choices about schools, is not conceived by Foucault (1982) as the freedom of a pre-existent self-determining individual that the state must control or regulate from above. Neoliberal discourses promote this conceptualisation of freedom, originating in classical liberalism, so that the 'truth' that we are responsible for our own choices (and their consequences) is sustained; it is a condition of the biopolitical process of 'responsibilization' (Foucault, 1978, pp. 104-105; Rose, 2006). Foucault (2008) conceptualises freedom as a discursive effect that varies historically but this does not mean that teachers are viewed as passive recipients and enactors of policies. A power relation only functions as such if the potential for resistance exists and there are always potential avenues of 'escape' or 'flight' (Foucault, 1982, p. 794).

Power relations do, however, work to condition or limit the range of actions available within historically specific social arrangements (Foucault, 1982, p. 790). Hence, as Moore and Clarke (2016, pp. 671-673) argue, the teacher who refuses a distinctly neoliberal discursive construction of professionalism risks the unpalatable prospect of being identified as unprofessional; similarly, teachers who insist that authentic educational inclusivity is only achievable through radical change in socio-political priorities risk being portrayed as obstructing progressive initiatives designed to further a social justice agenda (the greater good of inclusion of hitherto marginalised groups). More nuanced critique of policy is side-lined, leading to resistance often being expressed through less contentious arguments about workload which, following Moore and Clarke (2016), risk reinforcing the very discourses through which teachers are subjected (effective time-management being one aspect of the seductive discourse of professionalism).

What Foucault's (1982) concept of biopolitical power also suggests is that the state is not a monolithic, repressive and bounded entity; nor is government restricted to familiar political institutions. The modern state is, rather, the effect of different practices of governmentality and it governs, in part, through discourses and practices that instil a sense of personal freedom. The choices that are available to us may, in actuality, be highly circumscribed, but this sense of autonomy or self-government (and sense of responsibility for the 
choices made) is integral to modern practices of governmentality; as a power technology it is how the modern state governs (Foucault, 1978, 1982, 2008). The phrase 'responsibilising teachers', consequently, conveys a two-fold process. It denotes an increasing level of demands made on teachers as the state's role is transformed by marketisation and, more recently, within a politics of austerity. It also invokes the government of individualisation (Foucault, 1982, p. 781) as a practice, or constellation of power technologies, through which the state secures support for, and minimises resistance to, its policies. Both liberalism and neoliberalism introduce economy into the practice of politics and require particular forms of individualisation (Peters, 2007, p. 168).

\section{Ordo-liberalism(s)}

Freedom features prominently in the German school of neoliberal thought (ordo-liberalism) analysed by Foucault (2008) and described by Peters (2007, p. 168) as the 'European social model' or social market economy. The desire to reduce the size and power of the state through reliance on market mechanisms is ostensibly just as evident in ordo-liberalism as it is in other neoliberal economic theories, and this can be attributed to reactions against European fascism in the 1930s and 1940s (Foucault, 2008). However, it is the biopolitical dimension of ordo-liberalism that bears directly on the apparent contradiction referred to earlier (of intensified state intervention involving teachers despite an educational marketisation that is claimed to reduce such intervention). Since its inception in the 1930s, ordo-liberalism has combined reliance on the market with an explicit biopolitical concern with population regulation and the 'health' of the social body. Historically, fears about social (dis)integration prompted the incorporation of what Biebricher describes as a distinctly 'illiberal' (2011, p. 171) dimension into ordo-liberal thought. Suggestions that ordo-liberalism contains an ethical component (e.g. Peters, 2007; Rose, 2006) because its proponents recognised the value of supplementary state intervention, therefore, need to be read carefully; what is being outlined remains a form of governmentality that relies on familiar practices of biopolitical power.

Drawing on Foucault (2008), Peters (2007) contrasts two strands within ordo-liberal thought which are suggestive of inclusion-related governmental imperatives that teachers must now negotiate. In one (the Freiburg school), the market order is presented as a 'nondiscriminating, privilege-free order of competition' which is 'in and by itself an ethical order' (Vanberg, 2004, p. 2, cited in Peters, 2007, p. 170). In another (proposed by Muller-Armack), the market order is taken to be the 'most economically efficient order' but lacking 'inherent ethical qualities'; here, an ethical dimension must be supplied through supplementary social provisions and policies which may, or may not, 'conflict with the privilege-free nature of the rules of the game of the market' (Vanberg, 2004, p. 2, cited in Peters, 2007, pp. 170-171).

\section{Ordo-liberal inclusion(s)}

The discourse of inclusion as participation in high stakes testing outlined by Graham (2015) can be aligned with the first of these schools of neoliberal thought; inclusion here is discursively constructed as the right to participate (or freely compete) in a marketised educational culture characterised by high stakes testing, school league tables and 
heightened performativity, that is, in logics of standardisation and performance optimisation (Gannon, 2012; Lloyd, 2008). Hence, Graham (2015) tentatively endorses a recent Department of Education and Communities (New South Wales) policy that links funding for additional student support with inclusion in standardised assessment procedures. Graham (2015) maintains that this policy incentivises schools to increase the participation and performance of previously excluded school students in the high stakes testing associated with neoliberal marketisation. Developments in England, however, highlight the potentially negative consequences of such reliance on the market order; competition between schools has resulted in some mainstream schools located in areas of high social deprivation having over one-third of students who are classified as having 'special' educational needs, confirming Exley and Ball's (2011) suggestion that marketisation and policies ostensibly designed to include may actually work to sustain or exacerbate social and educational disadvantage.

The second school of ordo-liberal thought, with its marked biopolitical dimension that works to increase state intervention, directly implicates teachers. It is the teaching profession which the state requires to implement policies providing ethical supplementation; and this is how, we suggest, the neoliberal idealised abstraction of a reduced state is sustained. Historically, the socially funded segregation of pupils into so-called special schools represented an ethical supplement linked to the social market economy. The closure of many such institutions in England has produced a situation in which mainstream teachers themselves - their knowledge, practices and professional identities are discursively constructed as that ethical supplement. Although Norwich (2014) notes that attendance at special schools in England has recently increased after a sustained period of decline (suggesting that some parents remain sceptical about the benefits to their children of participation in high stakes testing and competitive marketised educational cultures), there has been a marked responsibilisation of mainstream teachers and schools in the area of inclusion. Accordingly, the shift away from 'professional responsibility' towards 'professional accountability' (Englund, 2011, p. 197) is, rather, a radical redefining of what professional responsibility entails that transcends the acquisition of neo-liberalised vocabularies associated with performativity.

Recent statutory guidance in England (DoH/DfE, 2015) stipulates that inclusion as participation in mainstream schooling is to be achieved through 'universal high quality inclusive teaching' or 'Quality First Teaching'. This guidance followed legislation in England (DfE, 2013) enabling parents to place children with multiple complex needs into mainstream settings. Both were preceded by a familiar political discourse about poor quality teaching exemplified by an Office for Standards in Education (OFSTED, 2010) report. The key assumption is that the relatively poor performance of pupils with special educational needs and disabilities signifies poor teaching practice (OFSTED, 2010).

Where teachers are charged with practising inclusively in order to (eventually) transform social norms, as in Florian and Graham (2014, p. 476), social change and inclusion policy enactment are effectively conflated (Ball et al., 2011, p. 617) such that questions about the purpose of education (McGregor, 2014) and of inclusion policies, and the role of teachers (Done, Knowler, \& Murphy, 2014), are precluded. The presentation of poor or inappropriate teaching practice as the key obstacle to inclusion responsibilises teachers who then become both problem and solution. Choosing not to self-improve in alignment with the governmental imperatives outlined in inclusion policies is unlikely to be 
experienced as a viable option for many teachers within professional contexts where training or continuing professional development is explicitly linked to incontestable social justice objectives. The presupposition that teachers can instigate and embed socio-political change through altering their own practices, values and professional identities leads, for example, to an apparent framing of the problem of inclusion as one of inadequate 'critical self-awareness' on the part of teachers (Florian \& Graham, 2014, p. 475) such that failure to effect the desired normative shift becomes, by implication, a matter of personalised professional failure. The 'cruel optimism' described by Moore and Clarke (2016, p. 666) thus becomes an equally cruel manipulation of 'conscience' (Foucault, 1982, p. 783).

Inclusion is now a site where distinctive versions of neoliberalism uneasily co-exist and act to responsibilise teachers through discourses which can be difficult to reconcile and enact at practice level, and this situation has been further complicated by discourses around austerity following the global financial crisis.

\section{Filling the void}

The aforementioned statutory guidance (DoH/DfE, 2015) requires teachers to adopt a 'graduated approach' whereby pupils identified as performing below age-related expectations must be provided with graduated levels or waves of support. As implied in OFSTED (2010), this approach assumes that teachers who can competently differentiate and respond to needs that are specific to particular conditions (diagnosed and otherwise) will make fewer demands on increasingly scarce economic resources. Teachers are effectively charged with enacting discourses of social justice within a context of diminished funding and against a wider discursive backdrop of national economic priorities dictated by a global market order. The theme of economic efficiency is repeatedly evidenced in the preceding legislation which, despite its demands on teachers, permits schools to limit the participation of all pupils in all school activities on economic grounds (Done et al., 2014). Political commitment to inclusive schooling, enshrined in the Salamanca Statement (UNESCO, 1994), has always been a matter of 'economic expedience', but the global financial crisis has exacerbated such trends.

Graham (2015) rejects the argument that inclusion as participation represents neoliberal buck-passing, yet the 'graduated approach' in England was the solution to a problem explicitly formulated by the UK's Coalition government (2010-2015) as an unaffordable over-identification of learning difficulties in the school population (Done et al., 2014). Subsequently, the 'good teacher' (Thompson \& Cook, 2014, p. 129), or professionalism (Moore \& Clarke, 2016), was discursively constructed as a mainstream teacher who not only delivers quantifiable improvement in all pupils (in competition for limited funding), but who also acquires expertise in diagnosable conditions, accurately identifying and addressing those which adversely affect pupil and school performance. Under the previous Coalition government and present UK Conservative government, reduced funding has limited the support that Local Authorities once provided to schools and teachers (Pearson, Mitchell, \& Rapti, 2015, pp. 53, 54). Early identification of diagnosable conditions and special educational needs was deemed an integral component of the teaching role (DoH/DfE, 2015) at precisely the time that support services, which schools have traditionally relied on to confirm their concerns, were being stretched beyond capacity. Delayed diagnosis via the Child and Adolescent Mental Health Services is widely reported by 
teachers in England, prompting SENCos (special educational needs coordinators) to organise in-school staff training by charitable organisations, for example, the British Autism Association, to assist teachers acquire the necessary expertise in specific diagnosable conditions and adapt their teaching practices and classroom environments accordingly.

\section{Caring and biopolitics}

A neoliberal modern state changes how teachers care for their students; Thompson and Cook (2014, p. 129) note an 'overlaying' of earlier educational discourses, in which pastoral care featured prominently, by one emphasising performativity; and they situate this change within a wider socio-historical shift towards the 'control' society (Deleuze, 1995, p. 177). The preface to a collaboration with Guattari written by Foucault suggests, however, that Deleuze did not regard Foucault's concept of pastoral power as defunct (Deleuze \& Guattari, 2009, pp. xiii-xiv). Just as the term 'overlaying' (Thompson \& Cook, 2014, p. 129) supports Foucault's (1982) argument that pastoral power continues as an integral component of biopolitical power, Deleuze (1995) is highlighting the 'globalizing and quantitative' knowledge used by the state to regulate populations (Foucault, 1982, p. 784), and the dividualising processes at play in performance comparisons involving large-scale data sets.

We would conceptualise such overlaying as an uneasy co-existence of differing modes of governmentality and subjectification, complicated by the versions of neoliberalism at play as exemplified in recent inclusion policy and legislation. Teachers are now instructed to care through a construction of caring as quantifiable mental or psycho-emotional health (DfE, 2016) and of the inclusive teacher as the professional who can deliver pastoral care and performance optimisation. Care is increasingly bound up with processes of systematisation, quantification, comparative measurement and accountability, hence schooldirected marketing promoting web-based assessment tools that purportedly permit teachers to identify, quantify and address deficits in psycho-emotional development through targeted ameliorative interventions. Care here looks remarkably like the pastoral power theorised by Foucault (1978), implying the management of a potentially unmanageable student sub-population; and, again, it is teachers who must not only provide this care but also quantified evidence of 'effective' caring within a context of diminished resources.

The promotion of parental involvement can also be read as an extension of pastoral power in which teachers are required to assume a biopolitical function (Lilley, 2014). It is not unusual for the authors to read teacher assignments detailing numerous parentdirected school initiatives (including dissemination of information on parenting, debt advisory services and relationship counselling), indicating a pastoral responsibility extending well beyond the confines of the school, and a biopolitical concern with the health of the (local) social body. This widened teacher remit evokes the feature of historical pastoral power identified by Foucault (1982): a dual focus on individual and community, but now coinciding with diminished resourcing of social provision.

\section{Producing professional identities}

Teachers have always provided the modern state with a 'relay' for social intervention (Foucault, 1982, p. 787, 2007, p. 104), but this role has been intensified in a resurgence 
of ordo-liberal thought following the global financial crisis (Biebricher, 2011, p. 171). The response of Pearson et al. (2015) to a mainstream practice landscape of diminished funding, inadequate external support and ever more complex student needs is pertinent to the issue of teacher identity. Teachers who are also SENCos are charged with ever greater 'resilience' and 'imagination' in the face of intensified accountability, timepressures and financial stringency (Pearson et al., 2015, p. 55). Imagination here is reduced to fulfilling the demands of a 'discourse of economic efficiency' and finding ways to ease the bureaucratic burden confronting SENCos as 'managed and managing professionals' within the neoliberal educational environment (Herr, 2015, p. 4). Such recommended responses to the problem of unsustainable bureaucratised workloads are suggestive of a characteristically neoliberal individualisation; individual teachers are invited to re-invent themselves and address personal deficits in areas such as timemanagement, efficiency, innovation and leadership (DoH/DfE, 2015).

The first version of neoliberalism outlined above (the Freiburg school) conflates inclusion and participation in the market order precisely because this neoliberal orientation asserts the intrinsically ethical nature of free competition; here, teachers are constructed as engaging in an ethical project which can be delivered unproblematically if 'poor' teaching is addressed (OFSTED, 2010). Under the second version of ordo-liberalism described, teachers function as an ethical supplement that is multi-faceted and which, when combined with the discourse of change management appearing in the inclusive educational literature (e.g. Lloyd, 2002; Graham, 2015), translates into a discursive invitation to change themselves in order to change society. Paradoxically, this latter construction involves bringing about socio-political change through becoming more like the individual demanded by the existing neoliberal market order. In the following section, we describe this discourse of commercial change management and its importation into educational discourse generally but, more specifically, into the literature relating to inclusive education.

\section{Individualised as agents of change}

Texts that present commercial change management concepts as generic, universally applicable and therefore relevant to education (e.g. Fullan, 1993, 2001) are increasingly cited in the inclusive education literature. Terminology from this discourse is used to produce a seductive image that teachers might identify with and affectively invest in, of themselves as key players in processes of socio-political and educational change; hence, 'effecting change', the 'change process' (Lloyd, 2002, p. 112, p. 118) and 'change agentry' (Florian \& Graham, 2014, p. 476). However, the role of 'change agentry', which Florian and Graham (2014, p. 476) insist teachers can fulfil, obscures the complexity of policy demands confronting teachers and schools (Ball et al., 2011, p. 617). As the latter observe, Fullan's $(1993,2001)$ presentation of businesses and schools as analogous ignores this complex policy environment. In commercial change management terms, the identification of and focus on 'key drivers' (actions having the greatest impact on particular problems within specified time frames) assumes a single tightly defined objective and an environment where such focus is viable (Rasiel \& Friga, 2002, p. 33); teachers, however, are rarely in a position to ignore competing educational policy agendas and governmental imperatives. 
This discourse of change management gained traction as a solution to the problem of complacency and its economic corollaries (failure to innovate, loss of market share and profitability, stagnation, insolvency) in large American corporations (Kotler, 1984). Competition within an increasingly globalised capitalism has facilitated a business environment in which the absence of marked change is perceived as a highly risky complacency, accompanied by a more generalised valorisation of change conceived as innovation. Within educational contexts, the risk for teachers questioning inclusion-related policy is that they are seen as complacent about the needs of all pupils and insufficiently innovative. Historically, teachers have been caught up in varied educational discourses organised around very specific political problems, for example, of elitism, meritocracy, equity and now inclusion (Deleuze, 2004). This is a very different proposition to that of complacency associated with market dominance and economic stagnation. Like the discourse of professionalism (Moore \& Clarke, 2016), this discourse of change management introduces a potentially divisive a 'system of differentiation' (Foucault, 1982, p. 792) affecting teachers.

The genericisation of a commercial change management discourse neglects key features of that discourse which bear upon policy implementation and what is demanded of whom. In a chapter entitled 'Managing Yourself', Rasiel and Friga (2002) assume that readers would 'like to get a little closer to the top of the corporate ladder' if they 'have not already reached it' (p. 174). This assumption that responsibility for performance optimising problem-solving is a function of seniority is problematic given the demographic composition of teachers who are also SENCos and required by English law to train for a mandatory postgraduate national award; a sizeable proportion of SENCos seeking accreditation are relatively junior members of teaching staffs who are mandated, nevertheless, to lead and manage strategic change, assess and monitor changes in the teaching practice of colleagues, and deliver upward trends in pupil performance data. Strategic change management is included in the training leading to accreditation (Done et al., 2014) and SENCos must monitor the progress of individual teachers and their school towards compliance and the stipulated whole-school inclusive culture (DfE, 2013).

The question as to what sort of educational system we are striving to include young people in (Graham \& Slee, 2008, p. 290) is side-lined when a politics of blame (Herr, 2015 , p. 4), evidenced in OFSTED (2010), is combined with a commercial discourse of change management to imply that educational cultures are radically changeable if only teachers would change themselves and their practice. Such suggestions reinforce political narratives which responsibilise teachers whilst discouraging both critical scrutiny of this genericisation process and alternative ways of defining the issue of inclusion. The affective import of this responsibilisation under conditions of diminishing funding, excessive workloads and intensified accountability is acknowledged in the practitioner-orientated literature directed at SENCos (e.g. Pearson et al., 2015, p. 55). Yet, the proposed solution of greater individual resilience and imagination reflects neoliberal demands for innovation; the appropriately individualised and responsibilised teacher is one who also innovates or readily delivers creative solutions to problems arising in the implementation of government policy. The import for teachers who are not designated SENCos is less frequently acknowledged; the former are to be scrutinised, led, changed and managed by the latter whose remit includes the identification of training requirements and ensuring that every teacher meets statutory obligations. 


\section{Dividing practices}

What Foucault (1982, p. 777) terms 'dividing practices' and 'systems of differentiation' (p. 792) are technologies of power. Inclusion as participation is linked to a wider objective of facilitating the eventual economic productivity of students such that their diagnosed conditions are no longer an obstacle to free competition in the labour market; an economy of moral worth is implied in which the potentially economically active are valued over those who are not (Done et al., 2014). Initiatives to include hitherto excluded students perpetuate such economies as students bring their labels with them; ameliorative neoliberal policy initiatives re-inscribe systems of differentiation (Graham \& Slee, 2008, p. 277), paradoxically normalising and naturalising the very differences which they claim to address (Allen, 2008; Pelletier, 2009; Popkewitz \& Lindblad, 2000; Slee, 2000). In Watson (2010, p. 98), all proposed neoliberal solutions to the problem of inclusion imply techniques of power and management of difference; the included are those rendered manageable through ascription of fixed social identities or needs defined as 'special' (p. 94). Ordo-liberal 'Vitalpolitik' ('politics of life') relies on a highly normative ideal of human dignity and perceives 'devitalization' as lack of 'order' and grounds for social intervention and regulation (Biebricher, 2011, pp. 182, 185, 189).

Dividing practices also affect teachers. Enacting policies against one's better judgment in order to avoid charges of un-professionalism (Moore \& Clarke, 2016) implies a similar moral economy or system of differentiation. Mandating SENCos to assess colleagues introduces such a system at school level, with SENCos risking their school's compliance but also charges of poor leadership skills if they fail to fulfil their remit. An analysis of policy types (Ball et al., 2011) suggests another variant on this theme; 'imperative' policies require an uncritical 'technical professional' in whom 'judgment is suspended and ethical discomforts put aside' (p. 612), and where 'compliance is key' (p. 613), whilst 'exhortative' policy discourses offer scope for creativity and professional judgment in the implementation of policy (p. 615). Teachers who fail to display appropriate levels of creativity risk being perceived as insufficiently 'enterprising' (Bailey, Olmedo, \& Ball, 2015).

\section{Conclusion}

Teachers are increasingly constructed as both the problem and the solution in matters of inclusion (e.g. OFSTED, 2010). A sense of personal responsibility is being fostered for educational outcomes despite factors which should be considered as a 'non-school explanation' in the differential performance of students and schools (Ball, 2010, p. 155). Foucault's (1978) concept of responsibilisation describes the complex processes through which individuals come to identify with policy objectives, and the discursive strategies through which potential tensions are managed when policy objectives are difficult to reconcile with others or with deeply held beliefs about the purpose of education. Foucault's (1982) account of the development of the modern state implies that teachers have always functioned as a vehicle or relay for state-initiated social intervention. This role was expanded in the ordo-liberal post-war European social model (Peters, 2007) and has been intensified in a resurgent ordo-liberalism following the global economic crisis and associated politics of austerity (Biebricher, 2011). 
The modern state presents a 'matrix of individualization or a new form of pastoral power', that is, biopolitical power (Foucault, 1982, p. 783). We have identified continuities between historical notions of salvation (a feature of pastoral power) and discourses of change agency (in the neoliberal biopolitical present). Both encourage the deferment or management of resistance and both therefore imply a 'cruel optimism' as precious pedagogic values continue to be undermined (Moore \& Clarke, 2016, p. 666). It has also been argued that Foucault's (2008) analysis of neoliberalism, specifically ordo-liberal theory, bears directly on a perplexing aspect of educational neoliberalisation: the proliferation of demands placed on teachers despite political discourses built around economic theories that explicitly link marketisation with a diminished role for the state. We have distinguished two strands within ordo-liberal thought and aligned high stakes testing, performativity and competition for funding with an ordo-liberalism in which the market order is viewed as intrinsically ethical. The alternative ordo-liberal conceptualisation, in which policies and practices are required to provide an ethical supplement to the market order, has generated numerous policies which teachers are required to implement. The concept of inclusion as participation brings tensions between these two strands into sharp relief and discourses relating to professionalism and change agency can be read, following Foucault (1982), as discursive strategies which avert or complicate resistance.

'Objectivizing' and 'dividing practices', in which individuals are ascribed defining characteristics and divided from others and from themselves (Foucault, 1982, pp. 777-778), play a crucial role in the 'government of individualization' (p. 781) and the complex power relations that produce teachers' social and professional identities.

\section{Disclosure statement}

No potential conflict of interest was reported by the authors.

\section{References}

Allen, J. (2008). Rethinking inclusive education: The philosophers of difference in practice. London: Springer.

Bailey, P. L. J., Olmedo, A., \& Ball, S. J. (2015). To infinity and beyond ... : Hierarchical governance: The teach for all network in Europe and the making of hearts and minds. European Educational Research Journal, 12, 492-512. doi:10.230/eerj.2013.12.4.492

Ball, S. J. (2010). New class inequalities in education: Why education policy may be looking in the wrong place! Education policy, civil society and social class. International Journal of Sociology and Social Policy, 30, 155-166. doi:10.1108/01443331011033346

Ball, S. J., Maguire, M., Braun, A., \& Hoskins, K. (2011). Policy subjects and policy actors in schools: Some necessary but insufficient analyses. Discourse: Studies in the Cultural Politics of Education, 32, 611-624. doi:10.1080/01596306.2011.601564

Biebricher, T. (2011). The biopolitics of ordoliberalism. Foucault Studies, 12, 171-191.

Deleuze, G. (1995). Negotiations. New York, NY: Columbia University Press.

Deleuze, G. (2004). Difference and repetition. London: Continuum.

Deleuze, G., \& Guattari, F. (2009). Anti-oedipus. London: Continuum.

DfE. (2016). Mental health and behaviour in schools: Departmental advice for school staff. London: Author.

DfE (Department for Education). (2013). Children and families bill (2013). London: HMSO.

DoH/DfE (Department of Health/Department for Education). (2015). Special educational needs and disability code of practice: 0-25 years. London: HMSO. 
Done, E. J., Knowler, H., \& Murphy, M. (2014). Mandatory accreditation for special educational needs co-ordinators: Biopolitics, neoliberal managerialism and the Deleuzo-Guattarian 'war machine'. Journal of Education Policy. doi:10.1080/02680939.2014.905872

Englund, T. (2011). The linguistic turn within curriculum theory. Pedagogy, Culture and Society, 19, 193-206. doi:10.1080/14681366.2011.582256

Exley, S., \& Ball, S. J. (2011). Something old, something new ... understanding conservative education policy. In H. Bochel (Ed.), The conservative party and social policy (pp. 97-118). Bristol: Policy Press.

Florian, L., \& Graham, A. (2014). Can an expanded interpretation of phronesis support teacher professional development for inclusion? Cambridge Journal of Education, 44, 465-478. doi:10.1080/ 0305764X.2014.960910

Foucault, M. (1978). The history of sexuality, volume one: An introduction. New York, NY: Pantheon.

Foucault, M. (1982). The subject and power. Critical Inquiry, 8(Summer 1982), 777-795. Retrieved from https://www.jstor.org/stable/1343197?seq=1\#page_scan_tab_contents

Foucault, M. (2007). Security, territory, population. Lectures at the Collège de France 1977-1978 (M. Senellart, Ed. and G. Burchell, Trans.). New York, NY: Palgrave.

Foucault, M. (2008). The birth of biopolitics: Lectures at the Collège de France 1978-1979 (M. Senellart, Ed. and G. Burchell, Trans.). New York, NY: Palgrave.

Fullan, M. (1993). Why teachers must become change agents. Educational Leadership, 50(6), 1-13.

Fullan, M. G. (2001). Leading in a culture of change. San Francisco, CA: Jossey Bass.

Gannon, S. (2012). Changing lives and standardizing teachers: The possibilities and limits of professional standards. English Teaching: Practice and Critique, 11(3), 59-77.

Graham, L. J. (2015). Reconceptualising inclusion as participation: Neoliberal buck-passing or strategic by-passing? Discourse: Studies in the Cultural Politics of Education. doi:10.1080/01596306. 2015.1073021

Graham, L. J., \& Slee, R. (2008). An illusory interiority: Interrogating the discourse/s of inclusion. Educational Philosophy and Theory, 40, 277-293. doi:10.1111/j.1469-5812.2007.00331.x

Gunter, H. M. (2012). Leadership and the reform of education. Bristol: The Policy Press.

Herr, K. (2015). Cultivating disruptive subjectivities: Interrupting the new professionalism. Education Policy Analysis Archives, 23(86). Retrieved from http://dx.doi.org/10.14507/epaa.v23.2097

Kotler, P. (1984). Marketing management: Analysis, planning and control (5th ed.). Englewood, NJ: Prentice Hall.

Lilley, R. (2014). Professional guidance: Maternal negotiation of primary school placement for children diagnosed with autism. Discourse: Studies in the Cultural Politics of Education, 35(4), 513526. doi:10.1080/01596306.2013.871226

Lloyd, C. (2002). Developing and changing practice in special educational needs through critically reflective action research: A case study. European Journal of Special Needs Education, 17(2), $109-127$.

Lloyd, C. (2008). Removing barriers to achievement: A strategy for inclusion or exclusion? International Journal of Inclusive Education, 12, 221-236. doi:10.1080/13603110600871413

Massumi, B. (1998). Sensing the virtual, building the insensible. Retrieved February 12, 2008, from http://www.brianmassumi.com/english/essays.html

McGregor, G. (2014). Getting beyond the 'hotch-potch of competing agendas': The need to develop a powerful curriculum for all young people. Discourse: Studies in the Cultural Politics of Education, 35, 151-159. doi:10.1080/01596306.2013.865304

Moore, A., \& Clarke, M. (2016). 'Cruel optimism': Teacher attachment to professionalism in an era of performativity. Journal of Education Policy, 31, 666-677. doi:10.1080/02680939.2016.1160293

Murphy, M., \& Done, E. J. (2014). Autism and intuitive practice as the art of the prevailing middle. Journal of Research in Special Educational Needs. doi:10.1111/1471-3802.12084

Norwich, B. (2014). Recognising value tensions that underlie problems in inclusive education. Cambridge Journal of Education, 44, 495-510. doi:10.1080/0305764X.2014.963027

Office for Standards in Education (OFSTED) (2010). The special educational needs and disability review: A statement is not enough. Retrieved from https://www.gov.uk/government/publications/specialeducational-needs-and-disability-review 
Pearson, S., Mitchell, R., \& Rapti, M. (2015). I will be 'fighting' even more for pupils with SEN: SENCO's role predictions in the changing English policy context. Journal of Research in Special Educational Needs, 15(1), 48-56.

Pelletier, C. (2009). Emancipation, equality and education: Rancière's critique of Bourdieu and the question of performativity. Discourse: Studies in the Cultural Politics of Education, 30, 137-150. doi:10.1080/01596300902809054

Peters, M. A. (2007). Foucault, biopolitics and the birth of neoliberalism. Critical Studies in Education, 48(2), 165-178. doi:10.1080/17508480701494218

Popkewitz, T., \& Lindblad, S. (2000). Educational governance and social inclusion and exclusion: Some conceptual difficulties and problematics in policy and research. Discourse: Studies in the Cultural Politics of Education, 21(1), 5-44.

Rasiel, E. M., \& Friga, P. N. (2002). The McKinsey mind: Understanding and implementing the problemsolving tools and management techniques of the world's top strategic consulting firm. New York, NY: McGraw Hill.

Rose, N. (2006). The politics of life itself: Biomedicine, power and subjectivity in the twenty first century. Princeton, NJ: Princeton University Press.

Rouse, M. (2008). Developing inclusive practice: A role for teachers and teacher educators. Education in the North, 16(1), 1-20. Retrieved from www.abdn.ac.uk/eitn/documents/issue16/EITN-1-Rouse. pdf

Slee, R. (2000). Talking back to power: The politics of educational exclusion. Paper presented at the International Special Education Conference, University of Manchester, 24-28 July. Retrieved from http://www.isec2000.org.uk/abstracts/keynotes/slee.html

Smith, W. C. (Ed.) (2016). The global testing culture: Shaping educational policy, perceptions, and practice. Oxford: Symposium.

Thompson, G., \& Cook, I. (2014). Manipulating the data: Teaching and NAPLAN in the control society. Discourse: Studies in the Cultural Politics of Education, 35(1), 129-142.

Thrift, N. (2006). Re-inventing invention: New tendencies in capitalist commodification. Economy and Society, 35(2), 279-306.

UNESCO. (1994). The Salamanca statement and framework for action on special needs education. Paris: Author.

Watson, C. (2010). Educational policy in Scotland: Inclusion and the control society. Discourse: Studies in the Cultural Politics of Education, 31, 93-104. doi:10.1080/01596300903465443 